\title{
Challenges and opportunities of microbial fuel cells (MFCs) technology development in Indonesia
}

\author{
Bimastyaji Surya Ramadan ${ }^{1, *}$ and Purwono ${ }^{2}$ \\ ${ }^{1}$ Environmental Engineering Department Faculty of Civil and Environmental Engineering Bandung Institute of Technology, 40132 \\ Bandung, Indonesia \\ ${ }^{2}$ Environmental Engineering Department Faculty of Engineering Diponegoro University, 50275 Semarang, Indonesia
}

\begin{abstract}
Indonesian government has committed to realize the goals of sustainable development in the field of energy as stipulated in Government Regulation Number 79/2014 on national energy policy. A feasibility study of the utilization of alternative energy is important for developing countries like Indonesia. It is expected to reduce dependence on fossil fuel use and meet the energy needs on rural areas in Indonesia. Microbial fuel cells (MFCs) is a potential source of electrical energy from waste that is rich in organic matter. Trends in research and development of Microbial Fuel Cells (MFCs) technology are increasing every year due to great opportunity to address a wide range of issues related to renewable energy needs, restoration of contaminated environment, water treatment electricity generators in remote areas and many more. MFCs can be used to treat domestic waste, biomass, algae, landfill leachate, agricultural runoff, and industrial waste. MFCs technology is a technology solution for cheap, fast, simple. MFCs use of technical challenges including low electricity production, current instability, and high internal resistance. Many challenges must be address, including a more detailed analysis in energy production, consumption, and application, understanding the relationship between the amount of electricity and contaminant removal, promoting the elimination of nutrients and optimizing system configuration and operations.
\end{abstract}

\section{Introduction}

Microbial Fuel Cells (MFCs) is a bio-electrochemical devices that capable to produce electrical current directly from organic substances due to metabolic activity of microorganism / bacteria (release of electrons outside the cells) from waste or spesific substrate [1]. Some microorganisms (exoelectrogens) can release electrons through direct contact with electrode, nanowires, or mediator. Electrodes are used as acceptor (anode) and donor electrons (cathode). MFCs can independently treat wastewater or integrated with other treatment units $[2$, 3]. This interesting technology can be more competitive due to its sustainability in generating green energy.

MFCs is becoming more interesting and attracting many researcher attention. It can be seen from the number of researchers which doing project on this field and the number of papers published and cited [4]. MFCs technology can be used to generate electricity, water, hydrogen and other chemicals compound $[5,6]$. A wide range of research has been made either by engineering the constituent materials (external circuits, cathode, anode, or membrane), architecture and design, as well as microorganisms that work in it to improve efficiency [2]. MFCs are also applied on field scale to monitor remote areas and combined with other treatment unit to treat wastewater. Although electricity production is still in a low level (maximum power production efficiency is \pm
$60 \%$ ), but this issue is regarded as a challenge for researchers to improve MFCs performance [7].

One achievement of sustainable development goals (SDGs) is access to clean, affordable and sustainable energy. Energy is a major contributor to climate change, which is producing greenhouse gases about $60 \%$ from total emission. Renewable energy becoming more preferable because of sustainability and more carbonneutral when compared with fossil fuels. Renewable energy development is expected to reduce dependence on fossil fuels and increase energy independence in each country [8]. Microbial fuel cells is one of wastewater processing technology with high energy efficiency. MFCs can be one of alternative energy source to achieve energy independence.

Indonesia Government Regulation number 79/2014 about National Energy Policy is a clear form of government efforts to realize sustainable development goals in the energy field. The policy is aimed for reducing fossil fuels uses to less than $25 \%$ and increasing renewable energy uses more than $23 \%$. Some region in Indonesia are not entirely energy self-sufficient so that it has not covered by electricity $( \pm .44 \%$ in rural areas and $10 \%$ in urban areas). Renewable energy has given a great benefit especially for areas that are not reached by electricity including increase the economic, social, and public health value.

\footnotetext{
* Corresponding author: bimastyaji@s.itb.ac.id
} 
In Indonesia, those kinds of energy are still minority used. There are some examples of renewable energy sources: geothermal, biofuels, liquefied coal, biomass and waste, solar, wind energy, and micro / mini hydro. Biomass has a great chance to fulfill the need of energy and also promote sustainability of energy sources. MFCs is a kind of energy derived from biomass which is directly producing electricity in order to supply energy to transportation sector and electricity needs [7, 9-10]. This article explains how MFCs technology is potential to develop, both in terms of research and its application in Indonesia.

\section{Microbial fuel cells (MFCs)}

Microorganisms in MFCs convert biodegradable organic matter in waste into electricity through a quite complicated biochemical process in anaerobic or anoxic conditions. MFCs typically consist of two chambers, anode and cathode which is separated by a separator such as membrane and/or salt bridges. Each chamber has electrode as an electrons conductor and microorganism life support. Chemicals / organic substrate are filled into anode chamber as an electron donor. Micro-organism break down the chemical substances and resulting free electrons which is transferred into electrode via nanowire, mediator, or direct contact with electrode. In the bio-cathode MFCs system, oxygen which are typically injected into system by aerator, can be replaced by plant or algae. Electron that is flowing from anode to cathode through external wire and resistor results an electrical current [2].

MFCs are able to convert chemical into electrical current directly and perform biochemical reactions in the absence of additional energy in the cathode chamber. However, this technology is still difficult to apply due to highly cost of MFC material fabrication (electrode, proton exchange membrane and mediator) and low power generation [11]. Various kinds of those limitations have been studied and solved by combining two or more technologies such as constructed wetland MFC [12], activated sludge MFC, and photosynthetic MFC [11]; optimizing the design such as single chamber MFC (membrane-less MFC), cascade MFC, tubular MFC, stacked MFC, bio-cathode, and air-cathode $\operatorname{MFC}[6,11]$; and applying MFC without mediator / mediator-less MFC [13].

\section{Current research in Indonesia}

MFCs research in Indonesia has been carried out on a laboratory scale. Dani Permana [14] conducted a preliminary investigation research on electricity production using yeast microbial fuel cell (S. cereviceae) with methylene blue as mediator. The results showed that methylene blue may indicated increasing fuel cell voltage, but there is a need for further research to confirm it. Studies using yeast is also done by Samudro [15] in which the yeast is able to decrease COD concentration on domestic waste and increase MFC's electricity production. Engineered microorganisms also done by Purwati [16] using E. coli bacteria as degrading microorganisms. In addition to a variety of microorganisms, there is also a wide research in different substrate that microorganism in MFCs can degrade. Hermawan [17] and Purwono [18] reported that industrial wastewater has been used as substrate and microorganism sources for MFCs process. Other substrates such as wastewater fisheries [19], vegetable bins [20], cow rumen [21] and wastewater from tempeh industry [22] may also be used as MFCs substrate.

\section{Challenges and opportunity}

\subsection{Energy status}

Indonesia is an archipelago geographically country $( \pm$ 17,500 islands). It has fourth largest population in the world after China, India and United States which is \pm 255 millions or $3.5 \%$ of the total world population. According to energy resources perspective, Indonesia has enormous energy resources consist of renewable and non-renewable resources. Population growth and abundance of natural resources make energy consumption levels of Indonesian people increase every year. More than $75 \%$ of energy used comes from nonrenewable energy resources such as oil, natural gas and coal. On the other hand, the use of renewable energy sources is still very low when compared with other countries. Exploration and exploitation is causing environmental pollution and limited amount of nonrenewable energy resources lead to attract more attention on renewable energy development. In 2009, Indonesia's energy needs are supplied by six major sources include crude oil, biomass, natural gas, coal, hydropower, and geothermal. The amount and share of those energy supply can be seen in Figure 1 [10].

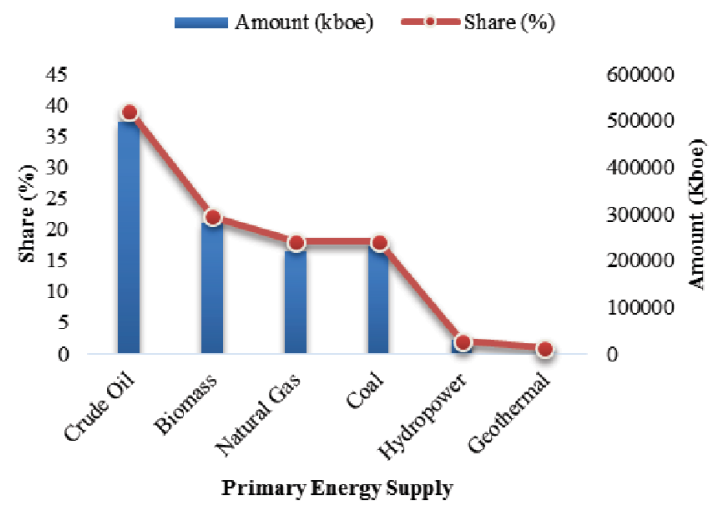

Fig. 1 Energy supply amount and share in Indonesia

Indonesia has a conducive geographical and geological conditions to develop renewable energy. Even so, these resources have not been utilized properly. Renewable energy that has been developed in Indonesia include hydropower, geothermal, solar, wind, and biomass. Among those five sources of energy, biomass is capable of producing the greatest amount of energy. It is a natural energy source that comes from plants, animal, 
and waste produced by living things. Biomass can produce three kinds of fuel products, namely liquid, solid and gas. Rice residue is the largest contributor of biomass fuel source followed by energy potential of rubber wood, sugar residues, and palm oil residues. Biodiesel and biogas are alternative fuels from biomass that are quite popular today. Biodiesel can replace diesel oil, because it is more environmentally friendly, capable to degrade by microorganisms, non-toxic, contains no sulphur and not produce black exhaust gas. Biogas can also be used as a source of potential energy primarily for location around livestock and landfill [10].

\subsection{Water resources}

High population density in Indonesia pose a serious threat to the environment. Economic pressures and rapid industrial growth led to the emergence of critical areas that are highly vulnerable to disasters such as floods, soil erosion and sludge production, lack of adequate water storage, watershed degradation, droughts, and water quality degradation. As a result, clean water supply is an issue that needs to be addressed. Low water service caused Indonesia has not been able to achieve Millennium Development Goals (MDGs) by 2013 because less than $50 \%$ of population does not get access to clean water (from target $68.8 \%$ ). Water pollution causes clean water price more expensive and worst. It is coming from human activities that are not environmentally responsible to water resources.

Regulation No. 7/2004 about water resources management in Indonesia is the first step for reform political administration to focus on water resources management issues. This law make stakeholders promise a commitment to manage water resources properly. Indonesian government together with stakeholders undertake water resource management that includes planning, monitoring and evaluation. Integrated water resources management is expected for effectively implemented in Indonesia. Nevertheless challenges faced quite heavy. It is form an institutional frameworks, facilities management, and environmental management. Recommended actions to address these challenges are integrated planning, water payment principles, a good management approach and coordinating model with all of stakeholders [23].

\subsection{MFCs Development Challenges and Opportunity in Indonesia}

MFCs Technology has many challenges to be faced as an alternative renewable energy source. MFCs can meet electricity needs in rural areas. Lee [11] states that algae can be used in the cathode chamber of MFCs system (bio-cathode) and anode filled with wastewater. Algae are capable of producing electrons acceptor in cathode chamber needed for the fuel cell takes place. MFC integrated with algae is divided into two reactors configuration: algae as bio-anode and algae as biocathode. MFCs with anode algae reactor is commonly called as microbial solar cells or photosynthetic microbial fuel cells. In this case, the algae serve as a producer of renewable energy. Meanwhile, cathode algae MFC is a reactor in which algae has a synergistic effect between algae growth and cathode reaction. MFC-based algae bioreactor is known to effectively remove COD and ammonium up to $90 \%$ as well as the production of electricity and biomass [24]. As an archipelagic nation with a fairly extensive sea and adequate sunlight (located on equator line area), Indonesia can take algae potential and combine it with MFCs.

MFCs are widely applied as wastewater treatment unit. Microorganisms in MFCs act as biocatalysts that could accelerate anaerobic treatment process on removing organic matter and chemical oxygen demand (COD) while the concentration is high. Anaerobic process that occur in MFCs is less energy consume make MFCs classified as an effective and efficient technology. Some researchers report that MFCs can be combined with trickling filters, activated sludge and anaerobic digester to improve treatment performance. A recent study explains that MFCs can produce electricity and hydrogen gas. It can remove more than $90 \%$ of COD and reach more than $80 \%$ of coloumbic efficiency. MFCs is also known to be used in wastewater with high salinity. Since MFCs are part of anaerobic process, MFCs can also be used to eliminate strong odour pollution that is often found in aerobic wastewater treatment such as activated sludge. MFCs can also be applied to wastewater with high concentrations of metals such as landfill leachate. Combination of membrane bioreactor and MFC has a good performance as capable of removing biomass and solids with high concentrations [25].

MFCs can also be used to restore land which contaminated with organic and inorganic chemicals. Sediment MFC (SMFCs) has shown a better recovery process of contaminated sediment by heavy metals pollution. From some studies, it has suggested that MFCs success to restore contaminated land by phenols and petroleum. MFCs are known to eliminate nitrate contained in groundwater [24]. In addition, SMFC also be used as biosensors that able to monitor environmental quality parameters such as groundwater and surface water in real time. When compared with conventional BOD monitoring, MFC biosensor is able to save costs due to the electricity needed for monitoring that are generated automatically by means of SMFCs [13]. The first step to implement biosensor is by adjusting the architectural design in remote area. BOD sensor based MFCs are known to operate and able for continuous monitoring for 5 years [25].

Other kind of MFCs development are microbial desalination cells (MDCs). Seawater desalination potency in Indonesia are open widely due to Indonesia consider as a country surrounded by vast oceans. MDCs are the answer for water crisis in urban and remote areas located close to the sea [5]. Reverse Osmosis (RO) system need large capital and energy consumption. MDCs significantly reduced energy requirements up to $0.5 \mathrm{kWh} / \mathrm{m}^{3}$ from $3-4 \mathrm{kWh} / \mathrm{m}^{3}$ in the common desalination process. More than $60 \%$ of energy can be 
saved through the MDCs. MDCs can also ease high concentrations salinity, which is more than $90 \%$ of salt can be removed and produce $31 \mathrm{~W} / \mathrm{m}^{3}$ power density [24].

Today, MFCs hybrid technology has been widely explored. MFCs are known to increase treatment process efficiency. When MFCs combined with aerobic nitrification, nitrate allowance increase and followed by electricity production. MFC-based electron fenton process was also developed to degrade recalcitrant organic compounds where MFCs role as the energy supplier for electron Fenton process. Various kinds of MFCs development continue to be done in order to compete in future market [24].

In developing countries such Indonesia, MFCs are promising to be applied because it is cheap, simple, fast and able to measure water quality parameters at the monitoring location. Many studies have been done show that indigenous bacteria contained in the Indonesian environment can support MFCs system. Although MFCs has many benefits and opportunities, this technology still needs to be studied more deeply to be applied in Indonesia. Low electricity production, high internal resistance and high material cost are the major obstacle of MFCs technology implementation [4].

Even though many studies reported that MFCs power generation and process effectiveness is quite good enough to implement but it was all achieved in a labscale. Stability, long-term performance, efficiency and scaling up process from lab scale to full scale are future challenges to be faced in by many researchers. Currently, it has developed open air bio-cathodes which is an example of MFCs engineered design to increase power output. Certain potential substrates is also being studied for possible implementation of MFCs in various types of wastewater. To improve the consistency and stability process, it is also conducted some research in a range of concentration, substrate, material and certain microorganisms [24, 26]. By improving cooperation among disciplines, MFCs may be a potential technology for solving water and renewable energy problem in Indonesia.

\section{Conclusion and Perspective}

MFCs is a technology that is experiencing rapid growth in terms of both research and application. MFCs capable to produce clean energy from the activity of microorganisms that could potentially be part of the renewable energy sources in Indonesia. MFCs technology are cheap, simple, fast and able to measure water quality parameters, also meet electricity needs in rural areas. Challenges of MFCs technology development in indonesia are low electricity, stability, long-term performance, and scaling up process from lab scale to full scale. Indonesia can take algae potential, wastewater from local industry as substrate, material, seawater desalination and indigenous microorganisms for combining it with MFCs.

\section{References}

1. Min Sun, Zha Lin-Feng, Li Wen-Wei and Yu HanQing, The Royal Society of Chemistry, 45, 28472870 (2016).

2. BE Logan, Microbial Fuel Cells, Hoboken, New Jersey: John \& Wiley Corp (2008).

3. Huang De-Yin, Zhou Shun-Gui, Qing Chen, Bo Zhao, Yong Yuan, Li Zhuang, Chemical Engineering Journal 172, 647-653 (2011).

4. Deepak Pant, Gilbert Van Bogaert, Ludo Diels, Karolien Vanbroekhoven, Bioresource Technology 101,1533-1543 (2010).

5. Li Xiaojin Li, Ibrahim M. Abu-Reesh and Zhen He, Agriculture 5, 367-388 (2015).

6. T Oh Sung., Jung Rae Ki, Giuliano C. Premier, Tae Ho Lee, Changwon Kim, William T. Sloan, Biotechnology Advances 28, 871-881 (2010).

7. Ieropoulos, I., Greenman, J. and Melhuish, C., Physical Chemistry Chemical Physics 14, 94-98 (2011).

8. Kaygusuz Kamil, Renewable and Sustainable Energy Reviews 16, 1116 - 1126 (2012).

9. Anonymous, Peraturan Pemerintah Republik Indonesia Nomor 7 Tahun, Jakarta (2014).

10. M.H. Hasan, T.M.I. Mahlia, Hadi Nur, Renewable and Sustainable Energy Reviews 16, 2316- 2328 (2012).

11. Lee Duu-Jong, Chang Jo-Shu, Lai Juin-Yih Lai, Bioresource Technology, 198, 891-895 (2015).

12. Doherty Liam, Zhao Yaqian, Zhao Xiaohong, $\mathrm{Hu}$ Yuansheng, Hao Xiaodi, Lei Xu, Liu Ranbin, Water Research 85, 38-45 (2015).

13. N Zeng, G Li, C Dorea, W Sloan, in 8th World Wide Workshop for Young Environmental Scientists www.yes-2009-Fr (19): urban waters : resource or risks? Jun 2009, Arcueil, France (2011).

14. Dani Permana, Desi Rosdianti, Safri Ishmayana, Saadah D. Rachman, Herlian Eriska Putra, Diana Rahayuningwulan, Hari Rom Hariyadi, Procedia Chemistry, 17, 36-43 (2015).

15. Ganjar Samudro, Sri Sumiyati, Bimastyaji S. Ramadan, Lintang Iradati, Prosiding Seminar Nasional Sains dan Teknologi Fakultas Teknik 1, 1 (2015).

16. Endang Purwati, Melda Latif, Hendri Purwanto dan Oki Andrean, Inovasi Sumber Energi, 40, 132-141 (2014).

17. Khanigia Vanessa Hermawan, Djaenudin, M. Rangga Sururi, Reka Lingkungan, Jurnal Online Institut Teknologi Nasional 2 (2014).

18. Purwono, Hermawan, and Hadiyanto, Jurnal Presipitasi 12 (2015).

19. Bustami Ibrahim, Pipih Suptijah dan Syeila Rosmalawati, JPHPI 17 (2014). 
20. Muhamad Imaduddin, Hermawan, dan Hadiyanto, Jurnal Sains Dasar 3, 196-204 (2014).

21. Rizki Januarita, Azka Azizah, Anis Ulfa W A, Hilma Syahidah, Ganjar Samudro, ejournal-s1 Undip, Semarang (2015).

22. Tania Surya Utami, Rita Arbianti, Deni Novitasari, Ester Kristin and Astry Eka Citrasari, in Proceedings of The 5th Sriwijaya International Seminar on Energy and Environmental Science \& Technology, Palembang (2014).

23. Mohamad Ali Fulazzaky, Water 6, 2000-2020 (2014).
24. Lei Xu, Zhao Yaqian, Doherty Liam, Hu Yuansheng and Hao Xiaodi, Critical Reviews in Environmental Sciences and Technology 46, 60-91 (2015).

25. Mostafa Rahimnejad, Arash Adhami, Soheil Darvari, Alireza Zirepour, Sang-Eun Oh, Alexandria Engineering Journal 54, 745-756 (2015).

26. Zhang Quanguo, $\mathrm{Hu}$ Jianjun, Lee Duu-Jong, Bioresource Technology 217, 121-128 (2016). 